\title{
Commentary on "Skin malignancy of the head and neck in Calabar, Southern Nigeria" by Asuquo
}

\author{
Ian Jackson
}

Received: 11 January 2010 / Accepted: 11 January 2010 /Published online: 20 February 2010

(C) Springer-Verlag 2010

Sir,

This paper was accepted for publication for several reasonsfor example, squamous cell carcinoma in this area of Africa is more common than basal cell carcinoma. This is the opposite compared to European skin cancers. The numbers are small, but they show trends of squamous cell carcinoma being first over all seconded by Kaposi's sarcoma.
I also hope that the publication of this paper will encourage other African plastic surgeons to submit some of their work. This would be greatly appreciated.

I thank and congratulate Doctor Asuquo for submitting such a nice study, and it is a pleasure to publish it in the European Journal of Plastic Surgery. 